\title{
Erratum to: Increasing the Richness of Culturable Arsenic-Tolerant Bacteria from Theonella swinhoei by Addition of Sponge Skeleton to the Growth Medium
}

\author{
Ray $\operatorname{Keren}^{1} \cdot$ Adi $\operatorname{Lavy}^{1} \cdot$ Micah Ilan $^{1}$
}

Published online: 27 February 2016

(C) Springer Science+Business Media New York 2016

Erratum to: Microb Ecol (2016)

DOI 10.1007/s00248-015-0726-0

Due to a typing error, the surnames and given names of the authors were switched. The given name of the first author is Ray and the Surname is Keren. The given name of the second author is Adi and the Surname is Lavy. The given name of the third author is Micha and the Surname is Ilan. The original version has been corrected.

The online version of the original article can be found at http://dx.doi.org/ 10.1007/s00248-015-0726-0.

\section{Ray Keren}

mr.ray.keren@gmail.com

1 Department of Zoology, George S.Wise Faculty of Life Sciences, Tel Aviv University, Ramat Aviv, Tel Aviv 6997801, Israel 